\author{
Volume 3, \\ Supplement Issue 2019: 1st Understanding Violence Congress, pp. 11-16 \\ E - ISSN: 2587-3008 \\ URL: http://ratingacademy.com.tr/ojs/index.php/jsp \\ DOİ: https://doi.org/10.26900/jsp.3.040 \\ Research Article
}

\title{
EVALUATION OF RADIOLOGICAL FINDINGS IN TERMS OF PHYSICAL ABUSE IN CHILDREN UNDER 4 YEARS OF AGE ADMITTED TO EMERGENCY DEPARTMENT
}

\author{
Nilüfer AYLANÇ* \& Esin AKGÜL KALKAN ** \& Şenay Bengin ERTEM *** \\ * Assist. Prof. Dr. M.D., Çanakkale Onsekiz Mart University, Faculty of Medicine, Radiology \\ Department,TURKEY, e-mail: niluferaylanc@gmail.com \\ ORCID ID: https://orcid.org/0000-0002-5889-9763 \\ ** Assoc. Prof. Dr. M.D., Çanakkale Onsekiz Mart University, Faculty of Medicine, Forensic \\ Medicine Department, TURKEY, e-mail: esina@comu.edu.tr \\ ORCID ID: https://orcid.org/0000-0002-7045-5401 \\ *** Assist. Prof. Dr. M.D., Çanakkale Onsekiz Mart University, Faculty of Medicine, Radiology \\ Department, TURKEY, e-mail: senay-ertem69@hotmail.com \\ ORCID ID: https://orcid.org/0000-0002-7237-6061
}

Received: 31 October 2019; Accepted: 15 November 2019

\begin{abstract}
Physical abuse is defined as non-accidental injury. For 0-3 years of age children, evaluated in the emergency department, the possibility of physical abuse should be considered. The purpose of this study is to discuss the role of radiological findings in the assessment of physical abuse suspicion. Children in 0-3 years of age, admitted with fall to the emergency department of a university hospital in 2018, were retrospectively evaluated on hospital automation system. Data was obtained from electronic health records. The cases were examined in terms of age, gender, falling features, physical and radiological findings related to trauma and suspicion of abuse. Data was analyzed in SPSS program. In 100 cases, 52 (52.0\%) were male and the mean age was $28.7 \pm 10.6$ months. The clinical diagnoses of the cases were 51 (51.0\%) falling from the same level, 11 (11.0\%) falling from one level to another, and 38 (38.0\%) 'only' falling. Posttraumatic radiological findings were as follows: 19 (19.0\%) cases had soft tissue injury with bone fracture and/or joint dislocation; 17 (17.0\%) cases had isolated soft tissue injury and $1(1.0 \%)$ had temporal bone fracture and intracranial traumatic changes. In $11(11.0 \%)$ cases had long bone fractures, 9 (9.0\%) were diaphyseal fractures. Two (2.0\%) cases had hand-finger, $1(1.0 \%)$ clavicle, $1(1.0 \%)$ calvarial and $1(1.0 \%)$ facial bone fractures. The case with clavicle fracture could not be evaluated in terms of physical abuse suspicion, because of unknown condition of walking. The suspicion of physical abuse was considered in 1 (1.0\%) case due to delay in hospital admission. Long bone diaphyseal fractures were most common in children aged 0-3 years. Since this finding showed low specificity to physical abuse, no suspicion of physical abuse was radiologically considered. The delay in hospital admission reveals the importance of evaluating cases from a multidisciplinary point of view in terms of suspicion of physical abuse.
\end{abstract}

Key words: Fall, physical abuse, forensic radiology. 


\section{INTRODUCTION}

Physical abuse is the harm to the child as a result of non-accidental (intentional) actions of individuals who take care of the child (Kar and Dokgöz, 2017; Özen et al., 2015). Physical abuse is more common in children under three years of age (Koç et al., 2014; Ayvaz and Aksoy, 2004); $12-20 \%$ of fractures observed in this age group are due to physical abuse (Flaherty et al., American Academy of Pediatrics Committee on Child Abuse and Neglect; Section on Radiology, Section on Endocrinology, and Section on Orthopedics, American Academy of Pediatrics). Society for Pediatric Radiology, 2014). There is a 5-10\% risk of mortality as a result of repeated physical abuse (Koç et al., 2014; Ayvaz and Aksoy, 2004); 90\% of deaths under five years, 41\% under one year (Ayvaz and Aksoy, 2004). Therefore, early and accurate diagnosis is critical in cases of physical abuse. In order to prevent the fatality of violence, clinicians should exclude suspicion of physical abuse in children aged 0-3 years (Kar and Dokgöz 2017; Koç et al., 2014; Kemp et al., 2008; Ayvaz and Aksoy, 2004.). Falling is very common in childhood (Flaherty et al., American Academy of Pediatrics Committee on Child Abuse and Neglect; Section on Radiology, Section on Endocrinology, and Section on Orthopedics, American Academy of Pediatrics; Society for Pediatric Radiology, 2014); however, it is reported that children exposed to abuse are more likely to admit to emergency services due to falls and home accidents (Beyaztaş et al., 2014). In case of suspected physical abuse, radiological imaging is performed depending on the child's age, history, complaints and physical examination findings (Christian and Committee on Child Abuse and Neglect, American Academy of Pediatrics, 2015; Kar and Dokgöz, 2017; Duffy et al., 2011). Radiological imaging may help to determine the severity and mechanism of injury and to make the differential diagnosis (Kar and Dokgöz, 2017). Prevention of omission of physical abuse cases is a prior condition for health care. However, there are few studies on the evaluation of radiological findings in terms of suspected physical abuse in children under three years of age. Therefore, the aim of this study is to discuss the role of radiological findings in the assessment of suspected physical abuse.

\section{METHODS}

\subsection{Study design, methods and materials}

This is a retrospective cross-sectional descriptive study. The population of the study was determined by scanning through the hospital automation system. Patients under the age of 4 years, who admitted to the emergency department of the university hospital in 2018 due to falls and who had radiographs and / or CT scans were included in the study. Data were obtained from electronic medical files. The authors declared that the research was conducted according to the principles of the World Medical Association Declaration of Helsinki "Ethical Principles for Medical Research Involving Human Subjects", (amended in October 2013). In this study, cases were examined in terms of age and sex, fall characteristics, physical and radiological findings related to trauma, and suspicion of physical abuse. Radiological images were evaluated by two radiologists and a forensic specialist.

\subsection{Definitions and the scope of study}

Criteria for suspected physical abuse in patients with fractures: No history of injury, history incompatible with injury, different histories reported by caregivers, revised histories, delayed admission to treatment, other findings suspecting abuse, accompanying symptoms (Skin findings, internal organ or CNS injury, etc.), multiple fractures, high specificity fractures, fractures in the child who could not walk. High specificity fractures were defined as classic metaphyseal lesions (bucket handle or corner fracture), rib fractures (especially posteromedial), scapula fractures, spinous process fractures, and sternal fractures (Flaherty et al., American Academy of Pediatrics Committee on Child Abuse and Neglect, Section on Radiology, Section 
on Endocrinology, and Section on Orthopedics, American Academy of Pediatrics; Society for Pediatric Radiology, 2014). In this study, we focused on radiological data and evaluated the parameters like high specificity fractures, multiple fractures and delayed admission to the treatment.

\subsection{Data collection and analysis}

The data were analyzed with SPSS (version 20.0; SPSS / IBM Inc., Chicago, IL, USA). The descriptive data were presented by numbers, percentages and mean.

\section{RESULTS}

\subsection{Descriptive characteristics of study group}

Among 100 cases examined, 52 (52.0\%) were male and the mean age was $28.7 \pm 10.6$ months. The clinical diagnoses of the cases were falling from the same level in $51(51.0 \%)$, falling from one level to another in $11(11.0 \%)$ cases and only 'falling' in 38 (38.0\%) cases. Electronical records did not include history, height and weight values and fall height (in $\mathrm{cm}$ or $\mathrm{m})$.

\subsection{Radiological findings}

Table 1. Radiologic modality and screening dates

\begin{tabular}{|l|l|}
\hline X-Ray & $81(81,0 \%)$ \\
\hline Computerized Tomography (CT) & $5(5,0 \%)$ \\
\hline X-Ray and CT & $10(10,0 \%)$ \\
\hline X-Ray, CT and Ultrasonography & $4(4,0 \%)$ \\
\hline First 24 hours & $99(99,0 \%)$ \\
\hline 2-3. days & $1(1,0 \%)$ \\
\hline
\end{tabular}

The types of radiological imaging and date of screening are shown in Table 1.

Posttraumatic radiological findings were as follows: soft tissue injury, fracture and / or dislocation in 19 cases $(19.0 \%)$; only soft tissue injury in 17 patients $(17.0 \%)$ and temporal bone fracture and intracranial traumatic finding in 1 patient $(1.0 \%)$. Long bone fracture was found in 11 cases $(11.0 \%)$ and 9 of them $(9.0 \%)$ were diaphyseal fractures. Two cases $(2.0 \%)$ had hand-toe, 1 (1.0\%) had clavicle, $1(1.0 \%)$ had calvarial and 1 had (1.0\%) facial bone fracture. In Table 2, the radiological findings of the forensic cases declared in the emergency department were seen; Table 3 shows condition of suspected physical abuse according to radiological findings in patients declared as forensic cases. 
Table 2. Radiological findings of patients declared as forensic cases in emergency department

\begin{tabular}{|l|l|l|}
\hline \multicolumn{2}{|l|}{} & \multicolumn{2}{l|}{ Forensic case declaration } \\
\hline Radiological findings & $\begin{array}{l}\text { Yes } \\
\mathbf{n}(\boldsymbol{\%})\end{array}$ & $\begin{array}{l}\text { No } \\
\mathbf{n}(\%)\end{array}$ \\
\hline Isolated soft tissue & $2(40,0)$ & $15(15,8)$ \\
\hline soft tissue +fracture/joint injury & $3(60,0)$ & $17(17,9)$ \\
\hline Traumatic finding & $0(0,0)$ & $63(66,3)$ \\
\hline Etiology & $1(20,0)$ & $50(52,6)$ \\
\hline Fall at the same level & $4(80,0)$ & $27(18,8)$ \\
\hline Fall from one to another level & $0(0,0)$ & $38(40,0)$ \\
\hline Fall, undefined & \multicolumn{2}{|l}{} \\
\hline Fracture & $1(20,0)$ & $1(1,1)$ \\
\hline Femur & $2(40,0)$ & $0(0,0)$ \\
\hline Facial and calvarial bones & $0(0,0)$ & $14(14,9)$ \\
\hline $\begin{array}{l}\text { Clavicle, humerus, radius, ulna, femur, tibia, hand/foot, finger, } \\
\text { pelvic }\end{array}$ & & \\
\hline
\end{tabular}

Table 3. Suspected physical abuse among patients declared as forensic cases according to radiological findings

\begin{tabular}{|l|l|c|}
\hline \multicolumn{1}{|c|}{ Forensic case declaration } \\
\hline $\begin{array}{l}\text { Suspected physical abuse due to } \\
\text { radiological findings }\end{array}$ & $\begin{array}{l}\text { Yes } \\
\mathbf{n}(\%)\end{array}$ & $\begin{array}{l}\text { No } \\
\mathbf{n}(\%)\end{array}$ \\
\hline No suspected physical abuse & $5(5,0)$ & $93(93,0)$ \\
\hline There is suspected physical abuse & $0(0,0)$ & $1(1,0)$ \\
\hline Could not be evaluated & $0(0,0)$ & $1(1,0)$ \\
\hline
\end{tabular}

According to the defined criteria, as a result of forensic radiological evaluation due to physical abuse suspicion: 1 case $(1.0 \%)$ with clavicle fracture could not be evaluated for suspected physical abuse because of unknown growth and development status. Due to delay in admission to emergency department, there was $1(1.0 \%)$ case of suspected physical abuse.

\section{DISCUSSION}

On radiological imaging, detection of multiple fractures or fractures with different healing stages, unexplained delay in admission to treatment and the presence of other findings suggestive of abuse cause suspicion of physical abuse (Flaherty et al., American Department of Pediatrics Committee on Child Abuse and Neglect; Radiology, Section on Endocrinology, and Section on Orthopedics, American Academy of Pediatrics; Society for Pediatric Radiology, 2014). In this study, the most frequent finding was long bone diaphyseal fractures in children younger than 4 years old presented to the emergency department due to falls. Although long bone fractures are a common finding, there was radiologically no suspicion of physical abuse, as they show low specificity for abuse. Finding of delayed admission to the treatment made us think that the suspicion of physical abuse should be evaluated from a multidisciplinary point of view. The absence of data about the history and growth and development of children was an important limiting factor in assessing the suspicion of physical abuse in patients with radiological fractures. The multidisciplinary approach to child physical abuse will play an important role in the fight against physical abuse. 


\section{CONCLUSIONS}

The results of our study were the necessity of the interpretation of radiological findings from a multidisciplinary point of view in case of suspected child physical abuse and the necessity to raise awareness among emergency staff about physical abuse. Accordingly, the possibility of physical abuse should be considered in 0-3 age children admitted to the emergency department due to falls (Özen et al., 2015; Koç et al., 2014; Ayvaz and Aksoy, 2004.). In order to discuss the role of radiological findings in differential diagnosis of suspected physical abuse, it may be useful to make research in different and larger patient groups.

\section{ACKNOWLEDGEMENTS}

The authors would like to thank to Department of Public Health for statistical analysis and revision. 


\section{REFERENCES}

AYVAZ, M., AKSOY, C., 2004. Çocuk istismar ve ihmali: Ortopedik yönleri. Hacettepe Tıp Dergisi, 35:27-33.

BEYAZTAŞ, F.Y., ÖZEN, B., BÜTÜN, C., 2014. Fiziksel çocuk istismarının incelenmesi. Medicine Science, 3(2):1315-3.

CHRISTIAN, C.W.; COMMITTEE ON CHILD ABUSE AND NEGLECT, AMERICAN ACADEMY OF PEDIATRICS., 2015. The evaluation of suspected child physical abuse. $\quad$ Pediatrics, $135(5) . \quad$ Available at: www.pediatrics.org/cgi/content/full/135/2/e1337.

DUFFY, S.O., SQUIRES, J., FROMKIN, J.B., BERGER, R.P., 2011. Use of skeletal surveys to evaluate for physical abuse: analysis of 703 consecutive skeletal surveys. Pediatrics, 127(1):e47-e52. Available at: www.pediatrics.org/cgi/content/full/127/1/e47.

FLAHERTY, E.G., PEREZ-ROSELlO, J.M,, LEVINE, M.A., HENNRIKUS, W.L.; AMERICAN ACADEMY OF PEDIATRICS COMMITTEE ON CHILD ABUSE AND NEGLECT; SECTION ON RADIOLOGY, AMERICAN ACADEMY OF PEDIATRICS; SECTION ON ENDOCRINOLOGY, AMERICAN ACADEMY OF PEDIATRICS; SECTION ON ORTHOPEDICS, AMERICAN ACADEMY OF PEDIATRICS; SOCIETY FOR PEDIATRIC RADIOLOGY, 2014. Evaluating children with fractures for child physical abuse. Pediatrics, 133(2): e477-e489. Available at:www.pediatrics.org/cgi/content/full/ 133/2/e477.

KAR, H., DOKGÖZ, H., 2017. Child Physical Abuse. Turkiye Klinikleri J Child PsychiatrySpecial Topics, 3(3):175-80.

KEMP, A.M., DUNSTAN, F., HARRISON, S., MORRIS, S., MANNI M., ROLFE, K., DATTA, S., THOMAS, D.P., SIBERT, J.R., MAGUIRE, S., 2008. Patterns of skeletal fractures in child abuse: systematic review. BMJ, 337:1518-26.

KOÇ, F., HALICIOĞLU, O., AKŞİT, S., 2014. Hangi bulgular fiziksel istismarı düşündürür? The Journal of Pediatric Research,1(1):1-5.

ÖZEN, B., BÜTÜN, C., BEYAZTAŞ, F.Y., 2015. Düşme nedeniyle acile başvuran 0-3 yaş grubu çocuklarda fiziksel istismarın incelenmesi. Adli Tip Dergisi, 29(1):12-21. 